\title{
Neuronal Death/Survival Signaling Pathways in Cerebral Ischemia
}

\author{
Taku Sugawara, Miki Fujimura, Nobuo Noshita, Gyung Whan Kim, Atsushi Saito, \\ Takeshi Hayashi, Purnima Narasimhan, Carolina M. Maier, and Pak H. Chan \\ Department of Neurosurgery, Department of Neurology and Neurological Sciences, and Program in Neurosciences, Stanford \\ University School of Medicine, Stanford, California 94305-5487
}

\begin{abstract}
Summary: Cumulative evidence suggests that apoptosis plays a pivotal role in cell death in vitro after hypoxia. Apoptotic cell death pathways have also been implicated in ischemic cerebral injury in in vivo ischemia models. Experimental ischemia and reperfusion models, such as transient focal/global ischemia in rodents, have been thoroughly studied and the numerous reports suggest the involvement of cell survival/death signaling pathways in the pathogenesis of apoptotic cell death in ischemic lesions. In these models, reoxygenation during reperfusion provides a substrate for numerous enzymatic oxidation
\end{abstract}

reactions. Oxygen radicals damage cellular lipids, proteins and nucleic acids, and initiate cell signaling pathways after cerebral ischemia. Genetic manipulation of intrinsic antioxidants and factors in the signaling pathways has provided substantial understanding of the mechanisms involved in cell death/survival signaling pathways and the role of oxygen radicals in ischemic cerebral injury. Future studies of these pathways may provide novel therapeutic strategies in clinical stroke. Key Words: Cerebral ischemia, apoptosis, signaling pathway, oxidative stress.

\section{INTRODUCTION}

Many studies have shown that reactive oxygen radicals play important roles in the pathogenesis of various neurological disorders, such as ischemia, trauma, and degenerative disease. They damage cellular macromolecules, such as lipids, proteins and nucleic acids and lead to cell injury and death. ${ }^{1,2}$ Besides these direct injuries, recent studies have shown that oxygen radicals are also involved in cell death/survival signaling pathways. ${ }^{1,3-5}$ As for ischemic injury, it is generally accepted that apoptosis plays a pivotal role in cell death in vitro after hypoxia. Recent studies also suggest that apoptotic cell death occurs in vivo in cerebral ischemia models. ${ }^{1,6}$ Experimental ischemia and reperfusion models, such as transient focal/global ischemia in rodents, have been thoroughly studied and the cumulative evidence suggests the involvement of cell survival/death signaling pathways in the pathogenesis of apoptotic cell death in the ischemic lesions. $^{7-11}$ In these models, reoxygenation

Address correspondence and reprint requests to Pak H. Chan, Ph.D., Neurosurgical Laboratories, Stanford University, 1201 Welch Road, MSLS \#P314, Stanford, CA 94305-5487. E-mail: phchan@leland. stanford.edu. during reperfusion provides a substrate for numerous enzymatic oxidation reactions. ${ }^{1,2}$ In this review, the mechanisms of cell death/survival signaling pathways after ischemia and the involvement of oxygen radicals in these pathways will be discussed.

\section{ISCHEMIC CELL DEATH SIGNALING PATHWAY}

\section{Mitochondrial pathway of apoptosis}

The cell death signaling pathway in mitochondria has recently been demonstrated in the ischemic brain with the release of mitochondrial cytochrome $c$, a water-soluble peripheral membrane protein of mitochondria and an essential component of the mitochondrial respiratory chain (FIG. 1, Table 1). ${ }^{12}$ Cytochrome $c$ is translocated from mitochondria to the cytosolic compartment after transient focal cerebral ischemia in rats,${ }^{13}$ in brain slices that are subjected to hypoxia-ischemia, ${ }^{14}$ and in vulnerable hippocampal CA1 neurons after transient global cerebral ischemia. ${ }^{9}$ Mitochondria are known to be involved in both the necrosis and apoptosis pathways, which depend on the severity of the insult or the nature of the signaling pathways. ${ }^{715-17}$ In most instances, severe cerebral ischemia renders the mitochondria com- 


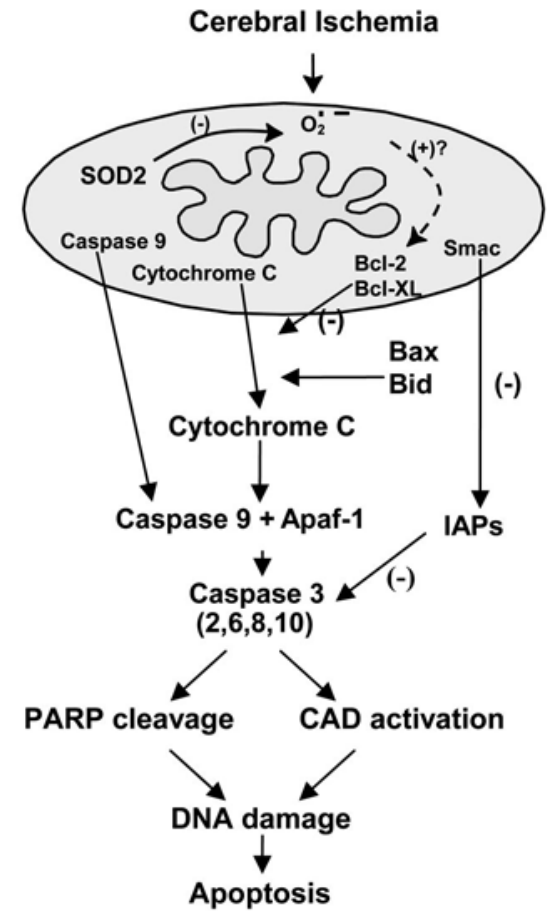

FIG. 1. Mitochondria as targets for oxidative stress signaling after cerebral ischemia. Cerebral ischemia and reperfusion generate ROS within mitochondria, which then signal the release of cytochrome $c$ by mechanisms that may be related to the $\mathrm{Bcl}-2$ family proteins, $\mathrm{Bcl}-2, \mathrm{Bcl}-\mathrm{X}_{\mathrm{L}}$, Bax, and Bid. Cytochrome $c$, once released, binds to Apaf- 1 followed by caspase- 9 to form a complex that subsequently activates caspase- 3 and other caspases, such as caspase-2, $-6,-8$, and -10 . The IAP family suppresses apoptosis by preventing the activation of procaspases and also inhibits the enzymatic activity of active caspases; Smac is also released by apoptotic stimuli and binds IAPs, thereby promoting activation of caspase-3. Activated caspase- 3 is known to cleave many nuclear DNA repair enzymes, such as PARP and to activate $C A D$, which then leads to nuclear DNA damage without repair, resulting in apoptosis. pletely dysfunctional for ATP production, which ensures necrotic cell death. In vitro studies demonstrate that various cellular or biochemical signaling pathways involve mitochondria in apoptosis by releasing cytochrome $c$ to the cytoplasm. Cytochrome $c$ interacts with the CED-4 homolog, Apaf-1, and deoxyadenosine triphosphate, forming the apoptosome and leading to activation of caspase-9. ${ }^{18-21}$ Caspase-9, which is presumably an initiator of the cytochrome- $c$-dependent caspase cascade, then activates caspase- 3 , followed by caspase- $2,-6,-8$, and -10 activation downstream. ${ }^{22}$ Caspase- 3 also activates caspase-activated DNase (CAD) and leads to DNA damage. In cerebral ischemia studies, caspase-3 and -9 have also been shown to play a key role in neuronal death after ischemia. ${ }^{10,23,24}$ Caspase-11 is also a critical initiator of caspase- 1 and -3 activation, and caspase-11 knockout (KO) animals have shown reduced apoptosis after focal ischemia. ${ }^{25}$ Since caspase-11 is an upstream activator of caspase- 1 in cytokine maturation, involvement of cytokines in apoptosis should also be considered after cerebral ischemia. The downstream caspases cleave many substrate proteins including poly(ADP-ribose) polymerase (PARP). ${ }^{23,24,26}$ Substrate cleavage causes DNA injury and subsequently leads cells to apoptotic cell death, but excessive activation of PARP causes depletion of nicotinamide-adenine dinucleotide and ATP, which ultimately leads to cellular energy failure and death. Consistent with these notions, PARP KO mice showed decreased infarct after transient middle cerebral artery occlusion (MCAO) ${ }^{27}$ In contrast, there are proteins that can prevent caspase activation in the cytosol. The inhibitor-of-apoptosis protein (IAP) family suppresses apoptosis by preventing the activation of procaspases and also by inhibiting the enzymatic activity of

TABLE 1. Transgenic and Knockout Studies of Proapoptotic and Antiapoptotic Proteins

\begin{tabular}{|c|c|c|c|}
\hline Study & Insult & Findings & Reference \\
\hline Bid-/- & Transient MCAO & Decreased infarct $(-67 \%)$ & Plesnila et al. ${ }^{35}$ \\
\hline Bcl-2 Tg & Permanent MCAO & Decreased infarct $(-50 \%)$ & Martinou et al..$^{34}$ \\
\hline $\mathrm{Bcl}-2 \mathrm{Tg}$ & Global ischemia & Decreased injury & Kitagawa et al. ${ }^{79}$ \\
\hline Bcl-2 Tg & Permanent MCAO & No protection & Wiessner et al. ${ }^{80}$ \\
\hline Bcl-2 Tg & Permanent MCAO & Decreased injury & de Bilbao et al. ${ }^{81}$ \\
\hline Bcl-2-I+, -I- & Transient MCAO & Increased infarct & Hata et al. ${ }^{36}$ \\
\hline $\mathrm{Bcl}-\mathrm{X}_{\mathrm{L}} \mathrm{Tg}$ & Permanent MCAO & Decreased infarct $(-21 \%)$ & Wiessner et al. ${ }^{80}$ \\
\hline Caspase-1 NM & Transient MCAO & Decreased infarct $(-44 \%)$ & Hara et al. ${ }^{82}$ \\
\hline Caspase-1 NM & Permanent MCAO & Reduced injury & Friedlander et al. ${ }^{83}$ \\
\hline Caspase-1-/- & Permanent MCAO & Reduced injury & Schielke et al. ${ }^{84}$ \\
\hline Caspase-1-/- & Transient MCAO & Decreased infarct & Liu et al. ${ }^{85}$ \\
\hline Caspase-11-/- & Permanent MCAO & Reduced apoptosis & Kang et al. ${ }^{25}$ \\
\hline PARP $-/-$ & Transient MCAO & Decreased infarct & Eliasson et al. ${ }^{86}$ \\
\hline PARP $-/-$ & Transient MCAO & Decreased infarct in chronic stage & Goto et al. ${ }^{87}$ \\
\hline Fas NM & Transient MCAO & Decreased infarct & Rosenbaum et al. ${ }^{39}$ \\
\hline TNFR(p55\&75)-/- & Transient MCAO & Increased injury & Bruce et al. ${ }^{41}$ \\
\hline TNFR(p55\&75)-I- & Transient MCAO & Increased injury & Gary et al. ${ }^{88}$ \\
\hline $\mathrm{P} 53-1+,-1-$ & Permanent MCAO & Decreased infarct $(-27 \%,-15 \%)$ & Crumrine et al. 89 \\
\hline
\end{tabular}

NM, negative mutant: TNFR, TNF-receptor- $\alpha$. 
active caspases. ${ }^{28,29}$ The second mitochondria-derived activator of caspase (Smac), is also released by apoptotic stimuli and binds IAPs, thereby promoting activation of caspase- $3 .{ }^{30}$ A recent study showed that mitochondrial release of cytochrome $c$ and Smac preceded caspase activation after global ischemia, suggesting the importance of IAP inhibition as well as caspase activation. ${ }^{10}$

The Bcl-2 family proteins have one or more Bcl-2 homology domains and play a crucial role in intracellular apoptotic signal transduction by regulating permeability of the mitochondrial membrane. ${ }^{31}$ Although still controversial, many researchers believe that mitochondrial cytochrome $c$ is released through the permeability transition pore (PTP), and that $\mathrm{Bcl}-2$ family proteins directly regulate the PTP. ${ }^{32}$ Among these proteins, Bax, $\mathrm{Bcl}_{\mathrm{S}} \mathrm{X}_{\mathrm{S}}$, $\mathrm{Bak}, \mathrm{Bid}$, and $\mathrm{Bad}$ are proapoptotic. They eliminate the mitochondrial membrane potential by affecting the PTP and facilitating the release of cytochrome $c .{ }^{33}$ Conversely, $\mathrm{Bcl}-2$ and $\mathrm{Bcl}-\mathrm{X}_{\mathrm{L}}$ function to conserve the membrane potential and block the release of cytochrome $c$. As expected, after focal cerebral ischemia, decreased infarct was observed in Bcl-2 overexpressing transgenic $(\mathrm{Tg})$ mice $^{34}$ and in Bid KO animals, ${ }^{35}$ whereas Bcl-2 KO mice showed an increased infarct. ${ }^{36}$ These findings, especially in the studies using proapoptotic/antiapoptotic protein$\mathrm{Tg} / \mathrm{KO}$ animals (Table 1), suggest the importance of mitochondrial permeability regulation and Bcl-2 family proteins in ischemic cerebral injury.

\section{Receptor-mediated pathway of apoptosis}

The death receptor pathway of apoptosis is initiated by members of the death receptor family, such as the Fas receptor and the tumor necrosis factor (TNF) receptor (FIG. 2, Table 1). For example, in the Fas receptor pathway, the extracellular Fas ligand (FasL) first binds to a receptor and an adaptor molecule, Fas-associated death domain (FADD) protein, then activates procaspase- $8 .{ }^{37}$ Subsequently, caspase- 8 activates caspase-3, and this effector caspase cleaves PARP and activates CAD, leading to DNA damage and cell death. In the middle of this pathway, caspase- 3 uses downstream caspases as in the mitochondrial pathway. ${ }^{38}$ Caspase- 8 is also able to truncate and activate one of the Bcl-2 family proteins, Bid, and to initiate the mitochondrial pathway of apoptosis. Increased expression of Fas and FasL was observed in the ischemic region after focal cerebral ischemia and the loss of Fas receptor function in negative mutant mice, resulting in a smaller infarct. ${ }^{39}$ In addition, Fas and FasL mRNA were induced, caspase-10 was activated and FADD was up-regulated in the vulnerable hippocampal CA1 subregion after global ischemia. Furthermore, caspase-3 and FADD were colocalized with caspase- $10^{40}$; this evidence strongly suggests involvement of the Fas receptor pathway of apoptosis after cerebral ischemia. Unlike Fas-receptor $\mathrm{KO}$ animals, TNF-receptor p55 and p75 KO mice ${ }^{41}$ showed

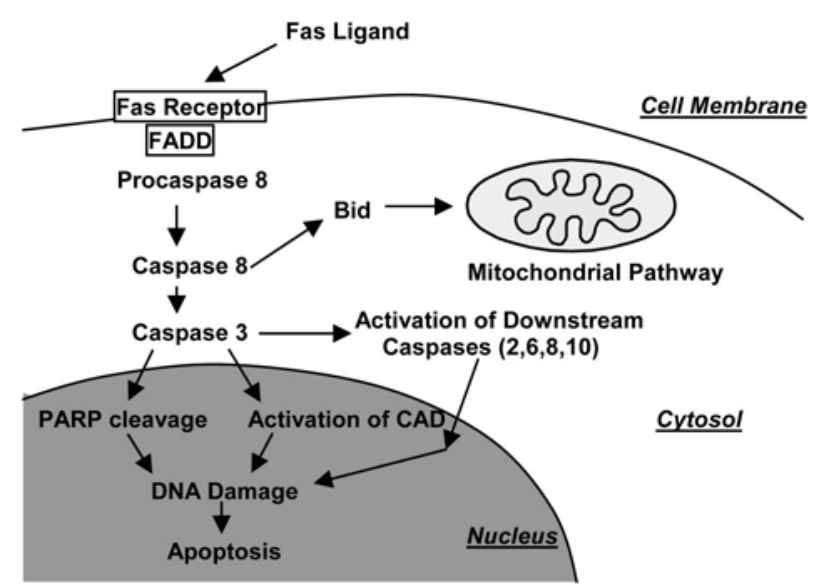

FIG. 2. Fas receptor pathway of apoptosis. The extracellular Fas ligand first binds to a receptor, and then an adaptor molecule, FADD protein, activates procaspase- 8 . Then, caspase- 8 activates caspase- 3 and this effector caspase cleaves PARP and activates CAD, leading to DNA damage and cell death. In the middle of this pathway, caspase- 3 uses downstream caspases as in the mitochondrial pathway. Caspase-8 is also able to truncate and activate one of the Bcl-2 family proteins, Bid, and initiates the mitochondrial pathway of apoptosis.

increased injury after transient focal ischemia, suggesting the neuroprotective effect of the TNF receptor. Results of these death receptor-KO studies also provide evidence that these receptors play an important role in cell death after ischemia (Table 1); however, the relationship between oxidative stress and receptor ligation is unknown and requires further studies.

\section{ISCHEMIC CELL SURVIVAL SIGNALING PATHWAY}

\section{Bad as a target of cell survival signaling}

Bad is an important proapoptotic member of the Bcl-2 family that links the upstream cell survival signaling pathway and downstream pathway to inactivate antiapoptotic Bcl-2 family proteins. ${ }^{42}$ In vitro studies show that Bad resides in an inactive complex with the molecular chaperone 14-3-3 via the phosphorylation of four serine residues (Ser-112, -136, -155, and -170$).{ }^{43}$ With apoptotic stimuli, Bad is dephosphorylated, dissociated from 14-3-3, and translocated to the outer membrane of mitochondria, where it subsequently dimerizes with $\mathrm{Bcl}-\mathrm{X}_{\mathrm{L}}$ and promotes mitochondrial cytochrome $c$ release. ${ }^{43}$ Ser-155 residue is important for direct interaction between $\mathrm{Bad}$ and $\mathrm{Bcl}-\mathrm{X}_{\mathrm{L}}$ and its phosphorylation is regulated by several upstream signaling pathways. After cerebral ischemia, dephosphorylation and translocation of Bad from the cytosol to the mitochondria are observed and dimerization of Bad progresses with $\mathrm{Bcl}-\mathrm{X}_{\mathrm{L}}$ in the early stages after MCAO. ${ }^{11}$ These results suggest the pivotal function of Bad in ischemic cell death (FIG. 3). 


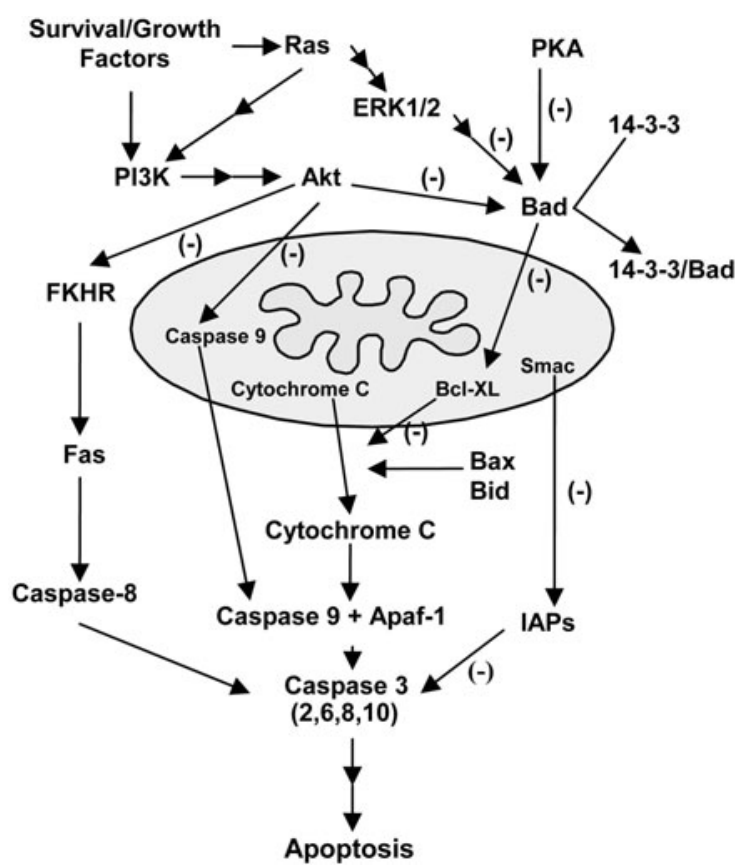

FIG. 3. Cell survival signaling pathways. Three major pathways that inhibit Bad are shown. Bad is an important proapoptotic member of the Bcl-2 family that links cell survival and apoptosis pathways. Bad promotes the release of cytochrome $c$ by inhibiting the antiapoptotic effects of Bcl- $X_{L}$. The phosphatidylinositol-3 kinase (PI3K) pathway is activated by survival/growth factors and leads to activation of Akt. Akt inhibits the Forkhead family of transcription factors (FKHR), caspase-9, and Bad, and ultimately leads to inhibition of both mitochondrial and Fas receptor pathways of apoptosis. ERK1/2 activation through active Ras and PKA also inhibit Bad and thereby block cytochrome $c$ release by $\mathrm{BCl}-\mathrm{X}_{\mathrm{L}}$ inhibition.

\section{Upstream survival signaling pathways for Bad inhibition}

There are several pathways to the inhibition of the proapoptotic function of Bad. Ras is considered to play a central role in signaling for growth-factor-mediated resistance to apoptosis. ${ }^{6}$ Recent studies have shown that pharmacological blockade of Ras results in an inhibition of the protective effects of ischemic preconditioning in primary cultures, and conversely, overexpression of Ras by transfection provides protection for cultured ischemic neurons. ${ }^{44}$ Ras can directly activate phosphatidylinositol-3 kinase, an upstream effector for activation of Akt. Akt is an initiator of the downstream pathways that inhibit the apoptotic pathways. Akt phosphorylates Bad and obviates its inhibitory effects on Bcl- $\mathrm{X}_{\mathrm{L}}$, ultimately inhibiting the release of cytochrome $c$ by blocking the channel formation on the mitochondrial membrane by Bax. ${ }^{6}$ Akt also inhibits proteolytic activity of caspase-9 by phosphorylating it on Ser-196. ${ }^{45}$ In addition, Akt can translocate into the nuclei and inactivate a proapoptotic member of the Forkhead family of transcription factors by phosphorylation, thereby inhibiting activation of the Fas pathway of apoptosis. ${ }^{46}$ Mitogen-activated protein kinase (MAPK) family members play a critical role in the regulation of cell growth, differentiation, and cellular response to cytokines and stress. ${ }^{47}$ One MAPK family member, extracellular signal-regulated kinase (ERK), has two isoforms (ERK1/2), which are constitutively expressed in the normal brain ${ }^{48}$ and are activated by MAPK/ERK kinase 1/2. In this pathway, Ras recruits the main effector, Raf-1, to activate MAPK/ERK kinase 1/2. ${ }^{49}$ Active ERK1/2 inactivates Bad through phosphorylation of 90-kDa ribosomal S6 kinases. ${ }^{50}$ Transforming growth factor- $\beta 1$ has been shown to suppress Bad activity by phosphorylation of Bad at the Ser-112 site via activation of the ERK pathway in both in vivo cerebral ischemia models and in vitro studies. ${ }^{51}$ Phosphorylation of ERK1/2 is thought to be involved in apoptosis and cell death after transient MCAO. ${ }^{8}$ Phosphorylation of the Ser-155 residue in Bad is regulated by protein kinase A (PKA) in studies in vitro. ${ }^{52}$ In rodent focal cerebral ischemia models, intraventricular injection of H89, a PKA inhibitor, effectively suppressed PKA activity ${ }^{53}$ and dimerization of $\mathrm{Bad} / \mathrm{Bcl}-\mathrm{X}_{\mathrm{L}}$ and subsequent apoptotic cell death. ${ }^{11}$ This cumulative evidence suggests that Akt, ERK1/2, and PKA pathways inhibit Bad function as cell survival signaling pathways after cerebral ischemia.

\section{OXIDATIVE STRESS AS A MOLECULAR SWITCH FOR ISCHEMIC CELL DEATH/SURVIVAL SIGNALING}

\section{Generation of oxygen radicals and clearance pathways}

Many studies have shown that reactive oxygen radicals play important roles in the pathophysiology of various neurological disorders. ${ }^{1,2,54,55}$ Experimental ischemia and reperfusion models, such as transient focal/global ischemia in rodents, have been thoroughly studied and the cumulative evidence suggests involvement of oxygen radicals in the pathogenesis of ischemic lesions. In these models, cerebral blood flow is reduced by occluded vessels in brain regions that are supplied with oxygen. Reoxygenation during reperfusion provides a substrate for numerous enzymatic oxidation reactions. Mitochondria produce superoxide anion radicals and hydrogen peroxide $\left(\mathrm{H}_{2} \mathrm{O}_{2}\right)$ under normal physiological conditions. ${ }^{56}$ These constantly produced reactive oxygen species (ROS) are scavenged by superoxide dismutase (SOD), glutathione peroxidase (GSHPx), and catalase. SOD specifically processes superoxide anion $\left(\mathrm{O}_{2^{-}}\right)$and produces $\mathrm{H}_{2} \mathrm{O}_{2}$, which is then detoxified by catalase or GSHPx, and finally changed to water and superoxide. Hydroxyl radicals $\left({ }^{-} \mathrm{OH}\right)$ may be generated from $\mathrm{H}_{2} \mathrm{O}_{2}$ through the Fenton reaction $\left(\mathrm{H}_{2} \mathrm{O}_{2}+\mathrm{Fe}^{2+} \rightarrow \mathrm{HO}+\right.$ $\left.\mathrm{Fe}^{3+}+{ }^{-} \mathrm{OH}\right)$. Other small molecular antioxidants, including glutathione (GSH), ascorbic acid, and $\alpha$-tocopherol, are also involved in the detoxification of free radi- 
TABLE 2. Transgenic and Knockout Studies of Superoxide Dismutases and Glutathione Peroxidase

\begin{tabular}{|c|c|c|c|}
\hline Study & Insult & Findings & Reference \\
\hline SOD1 +/- & Permanent MCAO & Decreased cortical infarct $(-35 \%)$ & Kinouchi et al. ${ }^{63}$ \\
\hline SOD1 +/- & Permanent MCAO & No protection & Chan et al. ${ }^{90}$ \\
\hline SOD1 +/- & Transient MCAO & Decreased infarct & Yang et al. ${ }^{91}$ \\
\hline SOD1 +/- & Transient MCAO & Sustained hsp70 mRNA expression & Kamii et al. ${ }^{92}$ \\
\hline SOD1 +/- & Transient MCAO & Sustained c-fos mRNA expression & Kamii et al. ${ }^{93}$ \\
\hline SOD1 +/- & Global ischemia & Induction of hsp70 & Kondo et al. ${ }^{94}$ \\
\hline SOD1 +/- & Transient MCAO & Decreased injury $(-50 \%)$ & Kamii et al..$^{95}$ \\
\hline SOD1 $+/-$ & Neonatal hypoxia & Increased injury in neonates & Ditelberg et al. ${ }^{96}$ \\
\hline SOD1 +/- & Neonatal hypoxia & Increased injury in neonates & Fullerton et al. ${ }^{97}$ \\
\hline SOD1 +/- & Global ischemia & Decreased injury $(-50 \%)$ & Chan et al. ${ }^{64}$ \\
\hline SOD1 $+/-$ & Global ischemia & Decreased injury $(-50 \%)$ & Murakami et al. ${ }^{69}$ \\
\hline SOD1 +/- & Transient MCAO & Decreased DNA fragmentation & Fujimura et al. ${ }^{98}$ \\
\hline SOD1 $+/-$ & Transient MCAO & Decreased cytochrome $c$ release & Fujimura et al. ${ }^{7}$ \\
\hline SOD1 +/- & Transient MCAO & Down-regulation of nuclear factor- $\kappa \mathrm{B}$ & Huang et al. ${ }^{99}$ \\
\hline SOD1 $+/-$ & Transient MCAO & Decreased activation of activator protein-1 & Huang et al. ${ }^{100}$ \\
\hline SOD1 +/- & Global ischemia & Decreased active caspase- $3,-9$ & Sugawara et al. ${ }^{10}$ \\
\hline SOD1 $+/-$ & Transient MCAO & Decreased ERK activation & Noshita et al. ${ }^{8}$ \\
\hline SOD1 +/- & Transient MCAO & Decreased Bad activation & Saito et al. ${ }^{11}$ \\
\hline SOD1 $-/-$ & Transient MCAO & Increased infarct $(+40 \%)$ & Kondo et al. ${ }^{67}$ \\
\hline SOD1 $-/-$ & Transient MCAO & Increased lesion size and edema & Kondo et al. 68 \\
\hline SOD1 $-/-$ & Global ischemia & Increased cell death & Kawase et al. ${ }^{66}$ \\
\hline SOD1 $+/-,-/-$ & Permanent MCAO & No increase in infarct volume & Fujimura et al. ${ }^{101}$ \\
\hline SOD2 $+1-$ & Transient MCAO & Decreased injury & Keller et al. ${ }^{71}$ \\
\hline SOD2 $-/+$ & Permanent MCAO & Increased infarct $(+66 \%)$ & Murakami et al. ${ }^{69}$ \\
\hline SOD2 $-/+$ & Permanent MCAO & Increased active caspase- 9 & Fujimura et al. ${ }^{70}$ \\
\hline SOD2 $-/+$ & Transient MCAO & Increased cytochrome $c$ release & Noshita et al. ${ }^{102}$ \\
\hline SOD2 $-1+$ & Permanent MCAO & Increased superoxide production & Kim et al. ${ }^{103}$ \\
\hline ECSOD $+/-$ & Transient MCAO & Decreased infarct $(-28 \%)$ & Sheng et al. ${ }^{72}$ \\
\hline ECSOD $+/+$ & Global ischemia & Decreased injury $(-48 \%)$ & Sheng et al. ${ }^{74}$ \\
\hline ECSOD $-1-$ & Transient MCAO & Increased infarct $(+81 \%)$ & Sheng et al. ${ }^{73}$ \\
\hline GSHPx-1 +/+ & Transient MCAO & Decreased infarct & Weisbrot et al. ${ }^{76}$ \\
\hline GSHPx-1 -/- & Transient MCAO & Increased apoptosis & Crack et al. ${ }^{77}$ \\
\hline
\end{tabular}

cals. Reperfusion after ischemia causes overproduction of ROS in mitochondria, and consumption of endogenous antioxidants by these radicals may lead to a dramatic rise in intracellular ROS. It has been demonstrated in numerous studies that ROS are directly involved with cellular macromolecules such as lipids, proteins, and nucleic acids in oxidative damage in ischemic tissues, which leads to cell death. Recent studies have provided evidence that indirect signaling pathways mediated by ROS can also cause cellular damage and death in cerebral ischemia and reperfusion.

\section{Antioxidant enzymes and studies using Tg and KO animals}

SODs are specific antioxidant enzymes that detoxify $\mathrm{O}_{2^{-}}$and produce $\mathrm{H}_{2} \mathrm{O}_{2}$. Three SODs, copper/zinc SOD (SOD1), manganese SOD (SOD2), and extracellular SOD (ECSOD), are major antioxidant enzymes based on cellular distribution and localization (Table 2). SOD1 is a major cytosolic enzyme with a level constituted at approximately $0.1 \%$ of total proteins in mammalian cells. SOD2 is a mitochondrial enzyme, whereas ECSOD is an isoform that is localized in extracellular space, cerebrospinal fluid, and cerebral vessels. ${ }^{57}$ All three SOD isoforms dismutate $\mathrm{O}_{2-}$, forming $\mathrm{H}_{2} \mathrm{O}_{2}$, which is scavenged by catalase or GSHPx at the expense of GSH. GSH is generated from oxidized GSH by GSH reductase in the presence of reduced nicotinamide adenine dinucleotide phosphate. Other lipid peroxides are also scavenged by GSHPx. SOD1 has been extensively used in experimental studies involving cerebral ischemia and reperfusion. Unfortunately, mixed and confusing results were obtained when free non-modified SOD1 was used. The extremely short half-life of SOD1 (6 min) in circulating blood and its failure to pass the blood-brain barrier and be taken up intracellularly, make it difficult to use for enzyme therapy in cerebral ischemia. ${ }^{58}$ However, a modified enzyme with an increased half-life, polyethylene glycol-conjugated SOD1, has been successfully used to reduce infarct volume in rats that were subjected to focal cerebral ischemia. ${ }^{59}$ Liposome-entrapped SOD1 has an increased half-life (up to $4.2 \mathrm{~h}$ ), blood-brain barrier permeability and cellular uptake, and has been proven to be an effective treatment for reducing the severity of ischemic and traumatic brain injuries. ${ }^{60,61}$ 
Numerous studies using genetically modified mice that either overexpress or are deficient in SODs have been published (Table 2). In SOD1-overexpressing Tg mice, a three-fold increase in SOD1 activity has been observed in all brain regions in heterozygous mice, whereas in homozygous mice, a five-fold increase in SOD1 activity was achieved. ${ }^{62}$ In these mice, a 35\% decrease in infarct volume was observed after permanent focal ischemia involving coagulation of the distal MCA and in bilateral common carotid artery occlusion. ${ }^{63}$ In global ischemia, SOD1 overexpression is neuroprotective, with a $50 \%$ reduction in hippocampal CA1 cell death, ${ }^{64,65}$ and this protection is probably partly due to blocking of the mitochondrial pathway of apoptosis. ${ }^{10}$ The role of SOD1 in cerebral ischemia is further confirmed by the use of SOD1-deficient mice. These SOD1 KO mice had increased cell death and edema after transient MCAO and global cerebral ischemia. ${ }^{66-68}$ The importance of mitochondrial production of oxygen radicals and the protective role of SOD2 after permanent cerebral ischemia have been demonstrated in SOD2 KO mice. These mutant mice show exacerbated infarct volume after permanent MCAO,${ }^{69}$ and increased mitochondrial cytochrome $c$ release and subsequent DNA fragmentation after permanent focal cerebral ischemia. ${ }^{70}$ However, mice that overexpress SOD2 showed neuronal protection against oxidative stress after transient focal cerebral ischemia. ${ }^{71}$ The ECSOD level in the brain is much lower than in other organs, but recent studies have demonstrated that overexpression of this protein provides protection after focal and global ischemia, whereas KO animals showed a larger infarct after focal ischemia. ${ }^{72-74}$ Results from pharmacological trials and studies using $\mathrm{Tg} / \mathrm{KO}$ rodents provide strong evidence to support the importance of SODs and superoxide in the pathophysiology of ischemic brain injury.

As described, superoxide generated in mitochondria was processed by SODs as a first step in its clearance pathway. This step generates $\mathrm{H}_{2} \mathrm{O}_{2}$, which is still a harmful ROS. Catalase and GSHPx catalyze the reduction of $\mathrm{H}_{2} \mathrm{O}_{2}$ to water and oxygen. Since constitutive catalase expression is at a low level in neurons compared with other organs, ${ }^{75}$ GSHPx is especially important for detoxifying $\mathrm{H}_{2} \mathrm{O}_{2}$ after cerebral ischemia and reperfusion. There are at least five mammalian GSHPx isoenzymes; GSHPx-1 is the most ubiquitous form, and localizes in the cytosol and mitochondria in most tissues. Neuronal injury in GSHPx-1 Tg and KO mice has been examined after focal ischemia (Table 2). Overexpression of human GSHPx-1 in Tg mice reduced the infarct volume by $48 \%$ after transient MCAO. ${ }^{76}$ Conversely, in GSHPx-1 KO mice, infarct volume was increased threefold and caspase-3 expression was present at earlier time points compared with wild-type animals. ${ }^{77}$ More recently, Crack et al. ${ }^{78}$ used a crossed SOD1 $\mathrm{Tg}$ mouse and
GSHPx-1 KO mouse model. These SOD1 Tg/GSHPx$1-/-$ crossed mice showed a larger infarct compared with wild-type mice. This study may suggest that despite a high level of SOD1, GSHPx activity needs to be maintained at a basal or higher level so that $\mathrm{H}_{2} \mathrm{O}_{2}$ and lipid peroxides, which are also generated during cerebral ischemia and reperfusion, can be eliminated.

\section{CONCLUSIONS}

From numerous results accumulated over the past decade, it is clear that oxidative stress is involved in cell death after cerebral ischemia. More recent studies strongly suggest the involvement of cell death/survival signaling pathways. Genetic manipulation of factors in the signaling pathways has provided substantial progress in understanding the mechanisms of apoptotic cell death and survival signaling pathways. Future studies of these pathways may provide novel therapeutic strategies in clinical stroke.

Acknowledgments: This study was supported by National Institutes of Health grants NS14543, NS25372, NS36147, and NS38653, and an American Heart Association Bugher Foundation Award. P. H. Chan is a recipient of the Jacob Javits Neuroscience Investigator Award.

\section{REFERENCES}

1. Chan PH. Reactive oxygen radicals in signaling and damage in the ischemic brain. J Cereb Blood Flow Metab 21:2-14, 2001.

2. Chan PH. Oxygen radicals in focal cerebral ischemia. Brain Pathol 4:59-65, 1994.

3. Lewen A, Matz P, Chan PH. Free radical pathways in CNS injury. J Neurotrauma 17:871-890, 2000.

4. Sugawara T, Lewen A, Gasche Y, Yu F, Chan PH. Overexpression of SOD1 protects vulnerable motor neurons after spinal cord injury by attenuating mitochondrial cytochrome c release. FASEB $J$ 16:1997-1999, 2002.

5. Liu R, Althaus JS, Ellerbrock BR, Becker DA, Gurney ME. Enhanced oxygen radical production in a transgenic mouse model of familial amyotrophic lateral sclerosis. Ann Neurol 44:763-770, 1998.

6. White BC, Sullivan JM, DeGracia DJ, O'Neil BJ, Neumar RW, Grossman LI et al. Brain ischemia and reperfusion: molecular mechanisms of neuronal injury. J Neurol Sci 179:1-33, 2000.

7. Fujimura M, Morita-Fujimura Y, Noshita N, Sugawara T, Kawase M, Chan PH. The cytosolic antioxidant copper/zinc-superoxide dismutase prevents the early release of mitochondrial cytochrome $\mathrm{c}$ in ischemic brain after transient focal cerebral ischemia in mice. $J$ Neurosci 20:2817-2824, 2000.

8. Noshita N, Sugawara T, Hayashi T, Lewen A, Omar G, Chan PH. Copper/zinc superoxide dismutase attenuates neuronal cell death by preventing extracellular signal-regulated kinase activation after transient focal cerebral ischemia in mice. $J$ Neurosci 22:79237930, 2002.

9. Sugawara T, Fujimura M, Morita-Fujimura Y, Kawase M, Chan $\mathrm{PH}$. Mitochondrial release of cytochrome c corresponds to the selective vulnerability of hippocampal CA1 neurons in rats after transient global cerebral ischemia. J Neurosci 19:RC39:1-6, 1999.

10. Sugawara T, Noshita N, Lewen A, Gasche Y, Ferrand-Drake M, Fujimura $\mathrm{M}$ et al. Overexpression of copper/zinc superoxide dismutase in transgenic rats protects vulnerable neurons against ischemic damage by blocking the mitochondrial pathway of caspase activation. J Neurosci 22:209-217, 2002. 
11. Saito A, Hayashi T, Okuno S, Ferrand-Drake M, Chan PH. Overexpression of copper/zinc superoxide dismutase in transgenic mice protects against neuronal cell death after transient focal ischemia by blocking activation of the Bad cell death signaling pathway. J Neurosci 23:1710-1718, 2003.

12. Boyer PD, Chance B, Ernster L, Mitchell P, Racker E, Slater EC. Oxidative phosphorylation and photophosphorylation. Аnпu Rev Biochem 46:955-1026, 1977.

13. Fujimura M, Morita-Fujimura Y, Murakami K, Kawase M, Chan $\mathrm{PH}$. Cytosolic redistribution of cytochrome $\mathrm{c}$ after transient focal cerebral ischemia in rats. $J$ Cereb Blood Flow Metab 18:12391247, 1998.

14. Perez-Pinzon MA, Xu GP, Born J, Lorenzo J, Busto R, Rosenthal $\mathrm{M}$ et al. Cytochrome $\mathrm{c}$ is released from mitochondria into the cytosol after cerebral anoxia or ischemia. J Cereb Blood Flow Metab 19:39-43, 1999.

15. Ankarcrona M. Glutamate induced cell death: apoptosis or necrosis? Prog Brain Res 116:265-272, 1998.

16. Bonfoco E, Krainc D, Ankarcrona M, Nicotera P, Lipton SA. Apoptosis and necrosis: two distinct events induced, respectively, by mild and intense insults with $N$-methyl-D-aspartate or nitric oxide/superoxide in cortical cell cultures. Proc Natl Acad Sci USA 92:7162-7166, 1995.

17. Green DR, Reed JC. Mitochondria and apoptosis. Science 281: 1309-1312, 1998

18. Kuida K, Haydar TF, Kuan CY, Gu Y, Taya C, Karasuyama H et al. Reduced apoptosis and cytochrome c-mediated caspase activation in mice lacking caspase 9. Cell 94:325-337, 1998.

19. Li P, Nijhawan D, Budihardjo I, Srinivasula SM, Ahmad M, Alnemri ES et al. Cytochrome c and dATP-dependent formation of Apaf-1/caspase-9 complex initiates an apoptotic protease cascade. Cell 91:479-489, 1997.

20. Yoshida H, Kong YY, Yoshida R, Elia AJ, Hakem A, Hakem R et al. Apaf 1 is required for mitochondrial pathways of apoptosis and brain development. Cell 94:739-750, 1998.

21. Zou H, Henzel WJ, Liu X, Lutschg A, Wang X. Apaf-1, a human protein homologous to C. elegans CED-4, participates in cytochrome c-dependent activation of caspase-3. Cell 90:405-413, 1997.

22. Slee EA, Harte MT, Kluck RM, Wolf BB, Casiano CA, Newmeyer DD et al. Ordering the cytochrome c-initiated caspase cascade: hierarchical activation of caspases- $2,-3,-6,-7,-8$, and -10 in a caspase-9-dependent manner. J Cell Biol 144:281-292, 1999.

23. Chen J, Nagayama T, Jin K, Stetler RA, Zhu RL, Graham SH et al. Induction of caspase-3-like protease may mediate delayed neuronal death in the hippocampus after transient cerebral ischemia. J Neurosci 18:4914-4928, 1998.

24. Namura S, Zhu J, Fink K, Endres M, Srinivasan A, Tomaselli KJ et al. Activation and cleavage of caspase-3 in apoptosis induced by experimental cerebral ischemia. $J$ Neurosci 18:3659-3668, 1998.

25. Kang SJ, Wang S, Hara H, Peterson EP, Namura S, AminHanjani $S$ et al. Dual role of caspase-11 in mediating activation of caspase-1 and caspase-3 under pathological conditions. J Cell Biol 149:613-622, 2000.

26. Endres M, Wang ZQ, Namura S, Waeber C, Moskowitz MA. Ischemic brain injury is mediated by the activation of poly(ADPribose)polymerase. J Cereb Blood Flow Metab 17:1143-1151, 1997.

27. Eliasson MJ, Huang Z, Ferrante RJ, Sasamata M, Molliver ME, Snyder SH et al. Neuronal nitric oxide synthase activation and peroxynitrite formation in ischemic stroke linked to neural damage. J Neurosci 19:5910-5918, 1999.

28. Deveraux QL, Reed JC. IAP family proteins-suppressors of apoptosis. Genes Dev 13:239-252, 1999.

29. Miller LK. An exegesis of IAPs: salvation and surprises from BIR motifs. Trends Cell Biol 9:323-328, 1999.

30. Chai J, Du C, Wu JW, Kyin S, Wang X, Shi Y. Structural and biochemical basis of apoptotic activation by Smac/DIABLO. $\mathrm{Na}$ ture 406:855-862, 2000.

31. Yuan J, Yankner BA. Apoptosis in the nervous system. Nature 407:802-809, 2000.
32. Shi Y. A structural view of mitochondria-mediated apoptosis. Nat Struct Biol 8:394-401, 2001.

33. Merry DE, Korsmeyer SJ. Bcl-2 gene family in the nervous system. Annu Rev Neurosci 20:245-267, 1997.

34. Martinou JC, Dubois-Dauphin M, Staple JK, Rodriguez I, Frankowski H, Missotten M et al. Overexpression of BCL-2 in transgenic mice protects neurons from naturally occurring cell death and experimental ischemia. Neuron 13:1017-1030, 1994.

35. Plesnila N, Zinkel S, Le DA, Amin-Hanjani S, Wu Y, Qiu J et al. BID mediates neuronal cell death after oxygen/glucose deprivation and focal cerebral ischemia. Proc Natl Acad Sci USA 98: 15318-15323, 2001.

36. Hata R, Gillardon F, Michaelidis TM, Hossmann KA. Targeted disruption of the bcl-2 gene in mice exacerbates focal ischemic brain injury. Metab Brain Dis 14:117-124, 1999.

37. Hengartner MO. The biochemistry of apoptosis. Nature 407:770$776,2000$.

38. Li H, Zhu H, Xu CJ, Yuan J. Cleavage of BID by caspase 8 mediates the mitochondrial damage in the Fas pathway of apoptosis. Cell 94:491-501, 1998

39. Rosenbaum DM, Gupta G, D'Amore J, Singh M, Weidenheim K, Zhang $\mathrm{H}$ et al. Fas (CD95/APO-1) plays a role in the pathophysiology of focal cerebral ischemia. J Neurosci Res 61:686-692, 2000.

40. Jin K, Graham SH, Mao X, Nagayama T, Simon RP, Greenberg DA. Fas (CD95) may mediate delayed cell death in hippocampal CA1 sector after global cerebral ischemia. J Cereb Blood Flow Metab 21:1411-1421, 2001.

41. Bruce AJ, Boling W, Kindy MS, Peschon J, Kraemer PJ, Carpenter MK et al. Altered neuronal and microglial responses to excitotoxic and ischemic brain injury in mice lacking TNF receptors. Nat Med 2:788-794, 1996.

42. Yang E, Zha J, Jockel J, Boise LH, Thompson CB, Korsmeyer SJ. $\mathrm{Bad}$, a heterodimeric partner for Bcl-XL and Bcl-2, displaces Bax and promotes cell death. Cell 80:285-291, 1995.

43. Zha J, Harada H, Yang E, Jockel J, Korsmeyer SJ. Serine phosphorylation of death agonist BAD in response to survival factor results in binding to $14-3-3$ not BCL- $\mathrm{X}_{\mathrm{L}}$. Cell 87:619-628, 1996.

44. Gonzalez-Zulueta M, Feldman AB, Klesse LJ, Kalb RG, Dillman JF, Parada LF et al. Requirement for nitric oxide activation of p21(ras)/extracellular regulated kinase in neuronal ischemic preconditioning. Proc Natl Acad Sci USA 97:436-441, 2000.

45. Cardone MH, Roy N, Stennicke HR, Salvesen GS, Franke TF, Stanbridge E et al. Regulation of cell death protease caspase- 9 by phosphorylation. Science 282:1318-1321, 1998.

46. Brunet A, Bonni A, Zigmond MJ, Lin MZ, Juo P, Hu LS et al. Akt promotes cell survival by phosphorylating and inhibiting a Forkhead transcription factor. Cell 96:857-868, 1999.

47. Raingeaud J, Gupta S, Rogers JS, Dickens M, Han J, Ulevitch RJ et al. Pro-inflammatory cytokines and environmental stress cause p38 mitogen-activated protein kinase activation by dual phosphorylation on tyrosine and threonine. J Biol Chem 270:74207426, 1995.

48. Boulton TG, Nye SH, Robbins DJ, Ip NY, Radziejewska E, Morgenbesser SD et al. ERKs: a family of protein-serine/threonine kinases that are activated and tyrosine phosphorylated in response to insulin and NGF. Cell 65:663-675, 1991.

49. Avruch J, Zhang XF, Kyriakis JM. Raf meets Ras: completing the framework of a signal transduction pathway. Trends Biochem Sci 19:279-283, 1994.

50. Frodin M, Gammeltoft S. Role and regulation of $90 \mathrm{kDa}$ ribosomal S6 kinase (RSK) in signal transduction. Mol Cell Endocrinol 151:65-77, 1999.

51. Zhu Y, Yang GY, Ahlemeyer B, Pang L, Che XM, Culmsee C et al. Transforming growth factor- $\beta 1$ increases Bad phosphorylation and protects neurons against damage. J Neurosci 22:3898-3909, 2002.

52. Lizcano JM, Morrice N, Cohen P. Regulation of BAD by cAMPdependent protein kinase is mediated via phosphorylation of a novel site, Ser155. Biochem J 349:547-557, 2000.

53. Kimura S, Uchiyama S, Takahashi HE, Shibuki K. cAMP-depen- 
dent long-term potentiation of nitric oxide release from cerebellar parallel fibers in rats. J Neurosci 18:8551-8558, 1998.

54. Kontos HA, George E. Brown Memorial Lecture: oxygen radicals in cerebral vascular injury. Circ Res 57:508-516, 1985.

55. Siesjo BK, Agardh CD, Bengtsson F. Free radicals and brain damage. Cerebrovasc Brain Metab Rev 1:165-211, 1989.

56. Boveris A, Chance B. The mitochondrial generation of hydrogen peroxide. General properties and effect of hyperbaric oxygen. Biochem J 134:707-716, 1973.

57. Marklund SL. Human copper-containing superoxide dismutase of high molecular weight. Proc Natl Acad Sci USA 79:7634-7638, 1982.

58. Chan PH, Kinouchi H, Epstein CJ, Carlson E, Chen SF, Imaizumi $\mathrm{S}$ et al. Role of superoxide dismutase in ischemic brain injury: reduction of edema and infarction in transgenic mice following focal cerebral ischemia. Prog Brain Res 96:97-104, 1993.

59. He YY, Hsu CY, Ezrin AM, Miller MS. Polyethylene glycolconjugated superoxide dismutase in focal cerebral ischemiareperfusion. Am J Physiol (Lond) 265:H252-H256, 1993.

60. Chan PH, Longar S, Fishman RA. Protective effects of liposomeentrapped superoxide dismutase on posttraumatic brain edema. Ann Neurol 21:540-547, 1987.

61. Imaizumi S, Woolworth V, Fishman RA, Chan PH. Liposomeentrapped superoxide dismutase reduces cerebral infarction in cerebral ischemia in rats. Stroke 21:1312-1317, 1990.

62. Chan PH, Epstein CJ, Kinouchi H, Kamii H, Imaizumi S, Yang G et al. SOD-1 transgenic mice as a model for studies of neuroprotection in stroke and brain trauma. Ann NY Acad Sci 738:93-103, 1994.

63. Kinouchi H, Epstein CJ, Mizui T, Carlson E, Chen SF, Chan PH. Attenuation of focal cerebral ischemic injury in transgenic mice overexpressing CuZn superoxide dismutase. Proc Natl Acad Sci USA 88:11158-11162, 1991.

64. Chan PH, Kawase M, Murakami K, Chen SF, Li Y, Calagui B et al. Overexpression of SOD1 in transgenic rats protects vulnerable neurons against ischemic damage after global cerebral ischemia and reperfusion. J Neurosci 18:8292-8299, 1998.

65. Murakami K, Kondo T, Epstein CJ, Chan PH. Overexpression of CuZn-superoxide dismutase reduces hippocampal injury after global ischemia in transgenic mice. Stroke 28:1797-1804, 1997.

66. Kawase M, Murakami K, Fujimura M, Morita-Fujimura Y, Gasche Y, Kondo T et al. Exacerbation of delayed cell injury after transient global ischemia in mutant mice with $\mathrm{CuZn}$ superoxide dismutase deficiency. Stroke 30:1962-1968, 1999.

67. Kondo T, Reaume AG, Huang T-T, Carlson E, Murakami K, Chen SF et al. Reduction of CuZn-superoxide dismutase activity exacerbates neuronal cell injury and edema formation after transient focal cerebral ischemia. J Neurosci 17:4180-4189, 1997.

68. Kondo T, Reaume AG, Huang T-T, Murakami K, Carlson E, Chen $\mathrm{S}$ et al. Edema formation exacerbates neurological and histological outcomes after focal cerebral ischemia in CuZn-superoxide dismutase gene knockout mutant mice. Acta Neurochir Suppl 70:62-64, 1997.

69. Murakami K, Kondo T, Kawase M, Li Y, Sato S, Chen SF et al. Mitochondrial susceptibility to oxidative stress exacerbates cerebral infarction that follows permanent focal cerebral ischemia in mutant mice with manganese superoxide dismutase deficiency. J Neurosci 18:205-213, 1998.

70. Fujimura M, Morita-Fujimura Y, Kawase M, Copin J-C, Calagui $\mathrm{B}$, Epstein $\mathrm{CJ}$ et al. Manganese superoxide dismutase mediates the early release of mitochondrial cytochrome $\mathrm{c}$ and subsequent DNA fragmentation after permanent focal cerebral ischemia in mice. J Neurosci 19:3414-3422, 1999.

71. Keller JN, Kindy MS, Holtsberg FW, St Clair DK, Yen HC, Germeyer A et al. Mitochondrial manganese superoxide dismutase prevents neural apoptosis and reduces ischemic brain injury: suppression of peroxynitrite production, lipid peroxidation, and mitochondrial dysfunction. J Neurosci 18:687-697, 1998.

72. Sheng H, Bart RD, Oury TD, Pearlstein RD, Crapo JD, Warner DS. Mice overexpressing extracellular superoxide dismutase have increased resistance to focal cerebral ischemia. Neuroscience 88: 185-191, 1999.
73. Sheng H, Brady TC, Pearlstein RD, Crapo JD, Warner DS. Extracellular superoxide dismutase deficiency worsens outcome from focal cerebral ischemia in the mouse. Neurosci Lett 267: 13-16, 1999.

74. Sheng H, Kudo M, Mackensen GB, Pearlstein RD, Crapo JD, Warner DS. Mice overexpressing extracellular superoxide dismutase have increased resistance to global cerebral ischemia. Exp Neurol 163:392-398, 2000.

75. de Haan JB, Bladier C, Griffiths P, Kelner M, O'Shea RD, Cheung NS et al. Mice with a homozygous null mutation for the most abundant glutathione peroxidase, Gpx1, show increased susceptibility to the oxidative stress-inducing agents paraquat and hydrogen peroxide. J Biol Chem 273:22528-22536, 1998.

76. Weisbrot-Lefkowitz M, Reuhl K, Perry B, Chan PH, Inouye M, Mirochnitchenko O. Overexpression of human glutathione peroxidase protects transgenic mice against focal cerebral ischemia/ reperfusion damage. Mol Brain Res 53:333-338, 1998.

77. Crack PJ, Taylor JM, Flentjar NJ, de Haan J, Hertzog P, Iannello $\mathrm{RC}$ et al. Increased infarct size and exacerbated apoptosis in the glutathione peroxidase-1 (Gpx-1) knockout mouse brain in response to ischemia/reperfusion injury. $J$ Neurochem 78:13891399, 2001.

78. Crack PJ, Taylor JM, de Haan JB, Kola I, Hertzog P, Iannello RC. Glutathione peroxidase- 1 contributes to the neuroprotection seen in the superoxide dismutase- 1 transgenic mouse in response to ischemia/reperfusion injury. J Cereb Blood Flow Metab 23:1922, 2003.

79. Kitagawa K, Matsumoto M, Tsujimoto Y, Ohtsuki T, Kuwabara $\mathrm{K}$, Matsushita $\mathrm{K}$ et al. Amelioration of hippocampal neuronal damage after global ischemia by neuronal overexpression of BCL-2 in transgenic mice. Stroke 29:2616-2621, 1998.

80. Wiessner C, Allegrini PR, Rupalla K, Sauer D, Oltersdorf T, McGregor AL et al. Neuron-specific transgene expression of $\mathrm{Bcl}-\mathrm{XL}$ but not Bcl-2 genes reduced lesion size after permanent middle cerebral artery occlusion in mice. Neurosci Lett 268:119_ 122, 1999.

81. de Bilbao F, Guarin E, Nef P, Vallet P, Giannakopoulos P, Dubois-Dauphin M. Cell death is prevented in thalamic fields but not in injured neocortical areas after permanent focal ischaemia in mice overexpressing the anti-apoptotic protein Bcl-2. Eur J Neurosci 12:921-934, 2000.

82. Hara H, Fink K, Endres M, Friedlander RM, Gagliardini V, Yuan $\mathrm{J}$ et al. Attenuation of transient focal cerebral ischemic injury in transgenic mice expressing a mutant ICE inhibitory protein. J Cereb Blood Flow Metab 17:370-375, 1997.

83. Friedlander RM, Gagliardini V, Hara H, Fink KB, Li W, MacDonald $\mathrm{G}$ et al. Expression of a dominant negative mutant of interleukin-1 beta converting enzyme in transgenic mice prevents neuronal cell death induced by trophic factor withdrawal and ischemic brain injury. J Exp Med 185:933-940, 1997.

84. Schielke GP, Yang GY, Shivers BD, Betz AL. Reduced ischemic brain injury in interleukin- $1 \beta$ converting enzyme-deficient mice. J Cereb Blood Flow Metab 18:180-185, 1998.

85. Liu XH, Kwon D, Schielke GP, Yang GY, Silverstein FS, Barks JD. Mice deficient in interleukin-1 converting enzyme are resistant to neonatal hypoxic-ischemic brain damage. J Cereb Blood Flow Metab 19:1099-1108, 1999.

86. Eliasson MJ, Sampei K, Mandir AS, Hurn PD, Traystman RJ, Bao J et al. Poly(ADP-ribose) polymerase gene disruption renders mice resistant to cerebral ischemia. Nat Med 3:1089-1095, 1997.

87. Goto S, Xue R, Sugo N, Sawada M, Blizzard KK, Poitras MF et al. Poly(ADP-ribose) polymerase impairs early and long-term experimental stroke recovery. Stroke 33:1101-1106, 2002.

88. Gary DS, Bruce-Keller AJ, Kindy MS, Mattson MP. Ischemic and excitotoxic brain injury is enhanced in mice lacking the p55 tumor necrosis factor receptor. J Cereb Blood Flow Metab 18: 1283-1287, 1998.

89. Crumrine RC, Thomas AL, Morgan PF. Attenuation of p53 expression protects against focal ischemic damage in transgenic mice. J Cereb Blood Flow Metab 14:887-891, 1994.

90. Chan PH, Kamii H, Yang G, Gafni J, Epstein CJ, Carlson E et al. Brain infarction is not reduced in SOD-1 transgenic mice after a 
permanent focal cerebral ischemia. Neuroreport 5:293-296, 1993.

91. Yang G, Chan PH, Chen J, Carlson E, Chen SF, Weinstein P et al. Human copper-zinc superoxide dismutase transgenic mice are highly resistant to reperfusion injury after focal cerebral ischemia. Stroke 25:165-170, 1994.

92. Kamii H, Kinouchi H, Sharp FR, Koistinaho J, Epstein CJ, Chan $\mathrm{PH}$. Prolonged expression of hsp70 mRNA following transient focal cerebral ischemia in transgenic mice overexpressing $\mathrm{CuZn}$ superoxide dismutase. J Cereb Blood Flow Metab 14:478-486, 1994.

93. Kamii H, Kinouchi H, Sharp FR, Epstein CJ, Sagar SM, Chan $\mathrm{PH}$. Expression of c-fos mRNA after a mild focal cerebral ischemia in SOD-1 transgenic mice. Brain Res 662:240-244, 1994.

94. Kondo T, Murakami K, Honkaniemi J, Sharp FR, Epstein CJ, Chan PH. Expression of hsp70 mRNA is induced in the brain of transgenic mice overexpressing human $\mathrm{CuZn}$-superoxide dismutase following transient global cerebral ischemia. Brain Res 737:321-326, 1996

95. Kamii H, Mikawa S, Murakami K, Kinouchi H, Yoshimoto T, Reola L et al. Effects of nitric oxide synthase inhibition on brain infarction in SOD- 1-transgenic mice following transient focal cerebral ischemia. J Cereb Blood Flow Metab 16:1153-1157, 1996.

96. Ditelberg JS, Sheldon RA, Epstein CJ, Ferriero DM. Brain injury after perinatal hypoxia-ischemia is exacerbated in copper/zinc superoxide dismutase transgenic mice. Pediatr Res 39:204-208, 1996.

97. Fullerton HJ, Ditelberg JS, Chen SF, Sarco DP, Chan PH, Epstein $\mathrm{CJ}$ et al. Copper/zinc superoxide dismutase transgenic brain ac- cumulates hydrogen peroxide after perinatal hypoxia ischemia Ann Neurol 44:357-364, 1998.

98. Fujimura M, Morita-Fujimura Y, Narasimhan P, Copin J-C, Kawase M, Chan PH. Copper-zinc superoxide dismutase prevents the early decrease of apurinic/apyrimidinic endonuclease and subsequent DNA fragmentation after transient focal cerebral ischemia in mice. Stroke 30:2408-2415, 1999.

99. Huang C-Y, Fujimura M, Noshita N, Chang Y-Y, Chan PH. SOD1 down-regulates NF- $\kappa \mathrm{B}$ and c-myc expression in mice after transient focal cerebral ischemia. J Cereb Blood Flow Metab 21:163-173, 2001.

100. Huang C-Y, Fujimura M, Chang Y-Y, Chan PH. Overexpression of copper-zinc superoxide dismutase attenuates acute activation of activator protein-1 after transient focal cerebral ischemia in mice. Stroke 32:741-747, 2001.

101. Fujimura M, Morita-Fujimura Y, Copin J-C, Yoshimoto T, Chan $\mathrm{PH}$. Reduction of copper, zinc-superoxide dismutase in knockout mice does not affect edema or infarction volumes and the early release of mitochondrial cytochrome $\mathrm{c}$ after permanent focal cerebral ischemia. Brain Res 889:208-213, 2001.

102. Noshita N, Sugawara T, Fujimura M, Morita-Fujimura Y, Chan $\mathrm{PH}$. Manganese superoxide dismutase affects cytochrome $\mathrm{c}$ release and caspase- 9 activation after transient focal cerebral ischemia in mice. J Cereb Blood Flow Metab 21:557-567, 2001.

103. Kim GW, Kondo T, Noshita N, Chan PH. Manganese superoxide dismutase deficiency exacerbates cerebral infarction after focal cerebral ischemia/reperfusion in mice: implications for the production and role of superoxide radicals. Stroke 33:809-815, 2002. 